\title{
Coming Out, Fitting in: The Personal Narratives of Some Irish Gay Men
}

\author{
PAUL RYAN \\ University College Dublin
}

\begin{abstract}
Through the personal narratives of four gay men coming of age during the 1970s, this paper questions the relevance of the modernist 'coming-out' story in Ireland. This story, so prevalent in British and North American studies documenting the history of the gay and lesbian movement there has remained largely untold in Ireland. This paper reveals a uniquely Irish 'coming-out' experience shaped by the schools, families and communities in which the men lived and whose stories cannot be adequately explained within a modernisation perspective so frequently used to explain social change in Ireland.
\end{abstract}

\section{Introduction}

This paper tells the story of four Irish gay men in the 1970s.' The stories reveal not merely the social world in which the men lived but allow us an insight into the major cultural sites in which Irish sexualities were affirmed, marginalised and resisted. I argue that it was within families, in Christian Brothers schools and on Gaelic playinggrounds that a unique sense of sexual confusion, anxiety and ultimately identity was produced. This identity reveals the complexity of Irish masculinities during this period and forced gay men to explore alternate strategies to affirm their homosexuality. These processes produced radically different stories from those told in the growing body of coming out literature that has emerged on both sides of the Atlantic since the late 1960s (Hall Carpenter Archives 1989, Nardi et al. 1994, Preston, 1991; Porter and Weeks 1991; Savin-Williams 1998). Similarly, the attempts of homosexual identity formation theorists to construct a modern, westernised coming out schema prove insufficient to explain the Irish coming out story, where school experiences are the key-determining factors influencing the extent of the isolation endured by the men rather than the same sexual encounters identified by Troiden (1988: 266) and others.

The use of stories is central to the exploration of the Irish coming out experience. Kearney (2002: 4) argues that narratives 'provide the most viable forms of identity' both individual and communal, and here they are used as a bridge between the individual experience and the broader cultural practices at work in 
Ireland in this period. There is a long tradition of telling stories in Ireland. Long before the advent of radio and television the retelling of religious stories, folktales, prayers and proverbs in the family home was commonplace, passed down through a rich oral heritage (O'Suilleabhain 1973). In the late twentieth century a new type of story is being told in Ireland. Plummer (1995: 54) identifies similar tales of a modernist age where stories of sexual suffering, endurance and an ultimate transformation of the individual take place. These stories are part of a broader process where individuals have sought to bring their private sexual lives into the public arena where they are constructed into narratives for public consumption. Recovery stories from rape, physical and sexual abuse are now familiar within the public domain in Ireland (see Milotte 1997; Raftery, 1999). While Kearney (2002: 11) dismisses the post-structuralist criticism of stories as being overly dependant on closure, I believe it has remained a predominant feature of this storytelling genre. The coming out story is told as an essential rite of passage, as a journey leading to a destination characterised by the transformation of the sexual self that often belies the complex and unique nature of the stories being told. ' Porter and Weeks (1991: viii) suggest the complexity of the coming out story in their collection, claiming that the stories were:

Insights into the complex, varied and uneven fashion by which homosexually inclined people made sense of their needs and desires and fashioned for themselves manageable, social and sexual ways of life.

A central concern of this paper is how these four Irish men fashioned a manageable sexual way of life within a culture hostile to homosexuality. ${ }^{3}$ The relative freedom granted to those growing up in post Stonewall America provided the impetus for those men and women who had harboured their secret sexuality to speak out about their past sexual lives. While it was Stonewall that had become the historical benchmark by which stories from America would be categorised, ${ }^{4}$ the Irish coming out story has been forged under very different circumstances.

\section{The Irish Coming Out Story}

While the gay and lesbian coming out story has been a familiar one since the late 1960s it has found little expression in Ireland. Previous analyses of the gay movement (Rose 1994: 1995) have concentrated on the legal and political strategies deployed to achieve the decriminalisation of homosexuality in 1993. There has been a neglect of the ordinary lived experience of gay men and in particular the economic and cultural practices which have prevented their stories from being told in the 1970s. Rose (1995: 73) describes the evolution of the gay moment as being the 'polar opposite' to the emergence of similar movements in other Western societies where our absence of modern, industrial ways of life would seem to condemn us to a profound sexual silence. Both Rose (1994) and Connolly (2002) reject this view of the Irish as backward on matters of sexual morality ignoring the early twentieth 
century networks men and women had created for themselves prior to the nationwide organisation of gay men and women. While the American pre-Stonewall stories fit neatly into a modernist narrative whereby the spread of capitalism, urbanisation and family change facilitated the growth of this storytelling genre, similar developments in Ireland failed to achieve the same results. Boyd's (1986) landmark text did tell the stories of Irish gay men and women some twelve years after the founding of the Irish Gay Rights Movement. The stories represent the successful coming out of people who would take a leading role in the movement that was just two years away from David Norris' victory in the European Court of Human Rights. But the story of ordinary gay men remained untold.

The presentation of Irish social change has most often been placed within a modernisation perspective (Breen et al. 1990, Goldthorpe \& Whelan, 1992). The dramatic economic policy change in 1958 marking the beginning of a process of modernisation in Ireland is a now familiar story. The socio-economic effects were dramatic. An expanding white collar and skilled manual workforce saw the decline of the agricultural labour force whilst Catholic social teaching became increasingly marginalised with the emergence of social partners reflecting a new corporatist thinking in Ireland (Breen et al. 1990: 6). Ireland's modernisation would hinge upon a radical overhaul of our cultural values and social institutions. It would be tempting to place the 'coming out' story in this framework of changing family and kinship patterns through much of the 1960s. This would underestimate the variations that existed within Irish family life. I agree with Fahey (1995: 210-11) that these variations, like the importance of older kinship networks in large industrial cities, illustrate the limitations of the traditional-modern dichotomy. Similarly, the stories of the men in this paper don't follow a linear, one-dimensional line of development. Nor are they presented as a form of gay victim-hood where gay sexuality is seen to be always problematic (see Mac an Ghaill 1994: 155). They are stories from a particular historical time in Ireland's development when people adapted to the socio-cultural change that swept the country during this period. This would seem to be part of the modernist promise. Berman (1988: 66) argues that urbanisation particularly, provided people with the anonymity necessary so that they were 'free to act' and free from the surveillance of neighbours, family and priests to grow and self develop. Within this environment individuals can recreate themselves within what Berman describes as a process of 'perpetual disintegration and renewal, of struggle and contradiction' (1988: 15). The connection between these processes and the formation of a gay or lesbian identity are clear. I agree with Bravmann (1996: 350) that it is the exaggerated political and personal significance attached to 'coming out' that has unified the gay and lesbian experience within this modernist narrative. Coming out becomes not an experience of individual liberation but rather a process of conforming and 'fitting into' existing middle class norms while often denying a previous working class background. It also denies the existing social and sexual networks that have been constructed by men prior to their coming out. The stories of the gay men in this paper reveal this narrative to be too narrow and 
unable to reflect the individual experiences to the coming out process often in areas where Berman's (1988) promise of anonymity and the removal of surveillance went unfulfilled in tight-knit urban neighbourhoods.

\section{Stories of Some Irish Gay Men}

From my perspective as the researcher, the narrative is used in a manner similar to that used by feminist researchers in their attempts to make women visible, often repairing the historical record about women's lives (Reinharz 1992: 126). ${ }^{6}$ I am less interested in trying to reclaim a unified gay past than gain an understanding of how individual gay men made sense of their social worlds. The interest lies in how individuals have constructed their experiences and the means by which they have used the past to legitimate their current sense of self (Nardi et al. 1994).

The narratives are based on a series of interviews carried out with eight men in Dublin between 1998 and 2000. The stories of four are presented here. Tim (50) a civil servant, Kieran (49) a health board manager and William (46) a primary school teacher, all born and raised in Dublin while Micheal (44), a life assurance agent was born in Co. Carlow. The men were recruited through a gay community website and selected on no other criteria than their age, and their willingness to speak about their lives. The men have various motivations for coming forward to tell their stories. Atkinson (1988: 24) and Lee (1993: 107) suggest there is often a purging or therapeutic element in the research process, and this is apparent in Tim's story. For Kieran and William the stories represent a contribution to a shared community building project identified by Martin (1988: 83). All the stories are products of memory and have been filtered through the reality of their present day lives. I have maintained a strong interest in the social relations of the research process. I have recognised that the men are the experts of their story and their voices are predominant and at times reflexive. This is in contrast to the researcher as expert who has within a tradition of positivist research colonised other people's stories, lives and experience (Lynch 2000: 80). I also have contributed to the creation of these stories. Through a shared identification (Lee 1993: 108) it is the interaction between their story and $m y$ story that the final text is produced. Lentin (2000: 18) reminds us of this interaction in the research process and the difficulty she felt when leaving the field after her research on daughters of Shoah survivors, because she was the field. I am also the field. As a gay man, educated by the Christian Brothers I have much in common with the men whose stories I am now responsible for and the shape in which they will be retold as they make their transition from the private to the public sphere. The empathy of this shared experience with the men in this study was vital in bridging the historical gap between their predominately urban coming of age in the 1970 s and my rural adolescence some eighteen years later. It was insufficient however in preparing me for the emotional consequences of such mutual disclosure and the difficulties in re-establishing professional boundaries after the narratives were completed. This disclosure removed much of the 
power in the research process creating a conversation between equals and a reformulation of the traditional relationship between the researcher and researched.

\section{Growing Up Gay? Sex and an Irish Childhood}

'My mother very much believed that children should be seen but not heard' (Tim).

There have been various theoretical schemas that have attempted to document the formation of homosexual identity in which childhood emotional and sexual contacts have featured (Plummer 1975; Cass 1979; Troiden 1988). Troiden (1988: 266) identifies these contacts in his sensitization stage where the child feels different and marginalised from their peers. These encounters may provide future reference points by which meanings are attached later in adolescence. I am not suggesting that we can apply such career path type schemas to a personal narrative study such as this; on the contrary these stories reveal the fallacy of pursuing some homogenous homosexual identity. Connell (1995: 148) for example reveals similar sexual encounters in his life stories of heterosexual men. The schemas do however reveal the pattern for a 'successful coming out' set out in the modernist framework that has become the basis of gay and lesbian coming out storytelling. For Troiden (1988: 173) the coming out story ends with commitment, an acceptance of ones homosexual identity. While identity formation theorists have attempted to construct a schema that can be applied to the coming out experience in modern, western industrial societies they often ignored key sociological insights. This is particularly evident in the Irish case. The identification of a nationalist sense of Irishness with Catholicism in the post-colonial Irish state sealed the dominance of the Catholic Church's role in the social and cultural life of Ireland (Fahey 1999: 57) and profoundly affected the experiences of young gay men in these years. I agree with Connell (1995: 150) that these experiences are social in origin and the homes in which the men in this study grew up were indeed conventional and governed by the existing construction of gender. Between the ages of nine and thirteen, three of the four men (the exception being Tim) had had sexual encounters with other boys in a similar age bracket. With the exception of Tim, three of the four men had childhood sexual encounters with other boys between the ages of nine and thirteen. What is significant about the descriptions of these encounters is the lack of transgression with which they were viewed. With the denial of childhood sexuality and the subsequent absence of any condemnation, these experiences are interpreted as a normal childhood occurrences. Where there was no language to describe their activities the boys remained free from any sexual categorisation, learning only in secondary school the penalties associated with their previously carefree childhoods.

William: I suppose the most important sexual encounter I can remember was with my cousin Brian; we were eleven or twelve on a beach at the time. it was just mutual masturbation and messing around. It happened and I had no language to contextualise it all, it was strange, exciting, pleasant and something I wanted to repeat. 


\begin{abstract}
Micheal: I was at some local event in our community hall, playing hide-and-seek and being in these bushes with a local girl called Alice, we were both eight or nine I imagine, when she pulled up her skirt and pissed right in front of me. I can remember being captivated by her because I was unsure of the dynamics of girl's bodies and where they actually peed from, she remained squatted down for sometime afterwards, I don't know what she wanted to happen but I was so out of there.
\end{abstract}

Kieran: I remember us having (his friends) sent away to a British comic called Warlord and getting back all this secret agent stuff and playing in the local graveyard. strangely enough and as part of that play there was always an amount of nudity involved (laughs) where people would be tracked down and stripped, I really can't remember what I thought of that behaviour, it seemed perfectly normal at the time.

That neither Micheal nor William possessed any sexual knowledge at this age is no surprise given the legacy of early Catholic based sex education. Inglis's (1998b: 24-26) review of that education places the discussion of sexuality within the natural law of God, couched in biological analogy that steers clear of the medical terms when explaining reproduction. Later in Micheal's adolescence his sexual naivety exposes him to a very real danger of molestation. In his last year of primary school Micheal's parents enrolled him into a ten-week first aid training course in the local Red Cross in a nearby town. Living four miles outside the town, Micheal often had to wait after class for his parents to pick him up, leaving him in the company of the course organiser, a man called Gerry.

Micheal: I think it was after only the second class that I found myself in Gerry's company after the class had finished and everybody had left. Sometimes we waited in the hall, which was the part of the local primary school and other times I'd wait with him in his car parked in front of the school (...) I think it started when he asked me the reason I wouldn't volunteer in class for demonstrations and was it because I was afraid I'd get an erection. I don't know what I said but I found myself alone with him on another two occasions when he kept on asking me about my body and erections and kept telling me he could help me get through this difficult transition in my life. He said he helped other boys with my problem. (...) I wasn't exactly sure what my 'problem' was; I wondered why he picked me out, I thought could he tell that I was all messed up inside? Well I didn't tell of course, I got dropped off at the school for the class and then hung around town till I was collected an hour later. I never went back.

For Micheal this was a defining moment of his adolescence. While admitting to being confused about his sexuality the fact that this confusion was visible from the outside encouraged Micheal to accept this definition of himself as gay at an earlier age. There were many other silences in the childhood homes of the men in this study. Tim grew up believing his parents' house was theirs, when in fact it was his grandmother's. If his parents ever had a house of their own, Tim doesn't know. His mother's 'illnesses' that dominated his childhood when she was confined to bed were also shrouded in secrecy. Later Tim discovers that his mother had suffered two miscarriages and one stillbirth during this time. Similarly, Kieran had no knowledge of his mother's ill health during his childhood. 
Tim: I suppose I understand my mother not wanting to tell a child what happened but when I was a teenager I did ask her but it was like some state secret (...) I got the feeling that she was more concerned with her extended family not finding out than us. but the children couldn't be told in case they let it slip. My mother very much believed that children should be seen but not heard. But I did have a baby brother or sister and its like they ve been wiped clean from our family's history, never to be mentioned again. My mother still won't talk about that time in her life.

Kieran: As children we didn't know what was wrong with our Mam. I don't remember her being sick I just remember her not doing the typical Irish mammy stuff for us. It turn out she suffered from bouts of depression, referred locally as 'trouble with her nerves".

Kieran is unclear as to the treatment his mother received for her 'nerves', an Irish euphemism akin to hysteria for a range of disorders synonymous with femininity.

The evidence from this study suggests that sport has played a central role in the direction and formation of the men's sexual development. The role of sport in men's lives has been examined by researchers utilising feminist methodologies (Messner 1987; Sabo and Runfola 1980) and is increasing seen as a site where hegemonic masculinity is reproduced and idealised. ${ }^{7}$

With the declining importance of physical strength in the world of work, sport offers boys a social currency by which they can display a physical masculinity. Masculinity becomes constituted in the bodily performance of sport exposing those who are 'lacking' in masculinity by their non-participation or exclusion. This exclusion has a profound effect, with the association between boys and sporting success, as a prerequisite to attaining status in adolescent and pre-adolescent peer groups being well documented (Whitson 1990; Gilbert and Gilbert 1998). In this study it is the extent to which the boys' rejection or exclusion from sport became equated with their homosexuality that is central. Pronger (1990: 113) argues that the association between sport and heterosexuality allows gay men a setting in which their sexuality is beyond suspicion, a setting in which they can 'pass for straight'. For Tim and William, their exclusion from their peer group was guaranteed by their rejection of sport while Kieran benefited from his association with sport, successfully concealing his sexuality from his peers.

William: I always believed that compulsory games was a way in which the Christian Brothers could exclude certain boys. I didn't play Gaelic football, the most popular game in our schools and my punishment was I remember having to write the same essay every Wednesday between 2-4pm: 'The Importance of Sport to Society'. I didn't think sport was very important at the time so I guess I must of lied.

Tim: I guess I was the stereotypical sickly child. I wheezed cause of my asthma if I ran around and to a degree it gave me sort of an immunity from sports. The scripts were written in the first week of school, we all were allocated our roles which we duly accepted: the comic, the nerdy brain box, the athlete and the fairy or the poofer, which was me.

Kieran: I can't remember if there was a division between the boys who played sport and those that didn't, sport was compulsory. The only option for those that didn't like 
sports was athletics, strangely enough. Those that were good at individual athletic events were encouraged. I had an interest in the long jump and the high jump and a Christian Brother would be assigned to you, I certainly never felt excluded by my lack of interest in sports.

Kieran seems unaware of the benefits he derives from his association with sport while Tim is unable to escape the definition of himself as a 'poofer' imposed on him by his lack of sporting success. Gaelic games were granted the greatest prestige by the Christian Brothers schools that the men attended. The manner in which the Gaelic Athletic Association (GAA) had constructed and romanticised Irish games for much of the nineteenth and twentieth centuries did much to equate the physical and moral fitness of the nation. By associating the pursuit of non-Gaelic past-times with effeminacy (Sudgen and Bairner 1993: 28-29) an outright rejection of Gaelic games would do much to diminish the masculinity of those involved.

\section{Brotherly Love: Speaking about Sex in a Christian Brothers School.}

'At school I presumed being gay was like being fat; I didn't think there was an activity involved' (William). ${ }^{8}$

School emerges as an important site in the sexual development of the men featured in this paper. All the men were educated by the Christian Brothers, a fact reflecting the importance of the order in the education of young men in the $1960 \mathrm{~s}$ and 1970s. Despite the modernisation project embarked on by successive governments since the late 1950s, secularisation, particularly within the education system, has been slow (Nic Ghiolla Phadraig 1995: 595). The Christian Brothers, like other religious orders had, since the mid-nineteenth century, consolidated their control of the education of Irish catholic boys. Keogh (1996: 97-98) sees the Christian Brothers as being part of a modernising process that swept Ireland in the early nineteenth century, playing a crucial role in the foundation of the modern church. As part of a modern civilising process, the Christian Brothers became responsible for the educational and moral needs of the unruly children of the working classes (Inglis, 1998a: 151). The virtues of discipline, chastity and cleanliness were instilled and reinforced through a system of surveillance by the Brothers themselves and through the guilt and shame the boys carried internally. The Christian Brother's emphasis on sobriety was seen to have been vital in the creation of a disciplined workforce. Similar efforts were made in Britain to extend a Christian manliness, characterised by organisations like the Boy Scouts and the extension of the public school philosophy to the urban working classes (see Mangan and Walvin 1987: 35-52).

The sexual curiosity of the men in this study continued to develop in school bringing them into direct conflict with the ideological nature of Christian Brothers schooling. Wolpe (1988: 100) reminds us that it is often the ideology of childhood sexuality that rejects schools being cultural sites where sexual identities can be formed. The discussion of sexuality within the Christian Brothers schools recalled in the stories share similar characteristics but the diversity of the stories lay within 
the individual acceptance, renegotiation or resistance to the sexual discourse. The discussion of sexuality lay within two distinct realms. It was firstly discussed within the context of science or later in biology classes. Tim remembers locating the section on sexual reproduction on page 138 of his science text, pages that were never dealt with by his teacher.

Tim: I read the pages over and over and I guess I understood but it wasn't me. what I was thinking and feeling just wasn't there, and your picking up bit of stories from older kids behind the bicycle shed and trying to piece it all together. Looking back. you're in this place that's supposed to be educating you but it's not, you're going through secondary school in total ignorance hoping no one would find out your secret, becoming more and more excluded.

The second realm in which sexuality was discussed was in the context of school retreats. Here, certain Christian Brothers deemed specialists in the area of sexuality would often take the students away from school once or twice a year for a day of prayer and reflection, a suitable context where sex could be discussed. The stories recalled by Tim, Kieran and Micheal bear striking similarities. The discussion of sexuality centred upon a categorical condemnation of masturbation. The elevation of masturbation as the greatest $\sin$ of male adolescence followed the historical precedent of educators in Britain and Ireland for much of the nineteenth century. Discussing masturbation became a means of discussing homosexuality by stealth. British nineteenth century educators had long believed that masturbation was the gateway to homosexuality and a range of other sexual vice and pursued it relentlessly (Weeks 1977: 25). This belief was grounded in the denial of childhood sexuality, seeing masturbation as a bridge to further sexual exploration. There is no doubt that medical advances, better housing and an awareness of nutrition did lower the age of puberty in the twentieth century increasing the perceived risk of adolescent sexuality (Gathorne-Hardy 1977: 357). Headmasters in Britain's public schools became agents of surveillance, seeking out and extracting confessions from those who had transgressed. Sermons were devoted to masturbation and prayers said for its suppression within the school walls. Trouser pockets were sewn up and lavatory doors removed to create virtual Victorian sexual concentration camps. With school libraries censored and stewards patrolling dormitories at night the repression seemed to generate the adolescent sexual activity that they were designed to eradicate (1977: 91). Foucault (1978: 28) suggests that this pursuit of adolescent masturbation was in itself designed to fail, serving only to bolster the power of those that initiated it through increased means of surveillance.

The four men in this study recall a similar condemnation of masturbation, particularly on school retreats organised by the Christian Brothers. This condemnation was remembered and interpreted differently by each of the men. For Tim it was devastating. Feeling increasingly isolated and finding no cultural support for his emerging gay feelings, Tim had resigned himself to a solitary sexual life. 
Tim: I was nineteen before I discovered that there was something called 'gay sex', as a teenager I thought the only way I could ever have sex was if I had a sex change so I thought it was just masturbation for the rest of your life and then I had the Catholic church telling me that even that solitary pleasure was a mortal sin.

For Kieran and William the condemnation of masturbation bore no relationship to their own experience of sex and what they witnessed in school. Kieran is adamant that the Christian Brothers were aware that a number of boys were engaged in mutual masturbation and oral sex in their Intermediate Certificate exam year and that no action was taken against them.

Kieran: Everybody knew about it, it was bizarre. I was in first year and I knew about it. I never had the good fortune to have sex with anyone in all my years in that school but with these six or seven lads it was generally known. The Brothers knew but nobody was expelled from school, maybe because nobody was caught. I've always suspected that it was because two of them were very bright and the Christian Brothers liked success in their school, academic and sporting. Mind you how would they have expelled these lads without talking about the sexual acts they were engaged in?

William: The real sexperts were the Holy Ghost fathers, they took us on retreat twice a year, and this is where we would hear about the evils of masturbation. Is it any wonder I thought I would be OK to have sex with someone else, just as long as I never did it on my own (laughs). Of course everyone in the class had wanked a thousand times before and the Holy Ghost fathers were probably prone to a jolly good wank themselves.

There is little doubt that the sexuality of the men in study has been shaped by their exposure to this religious condemnation of masturbation and the silence imposed on homosexuality. I agree with Foucault (1978: 29) that it would be inaccurate to see the school as having imposed a silence on the speaking of sex upon adolescents when the school in fact multiplied the number of discourses in which sex could be spoken. For Foucault the central feature concerned who was conferred with the power to speak about sex and who was not. Within the Christian Brothers, it was in the context of school retreats that discussion of sexuality was permitted. Beyond this, it was the other 'experts' in the fields of science education that were allowed to do so. So there were many silences within the Christian Brothers. Tim describes the treatment of a former Brother and teacher at his school:

Tim: My school recently produced a book to celebrate its anniversary or something and it listed all the teachers, past and present and some notable students that had gone on to greater and better things but I was struck by the absence of one teacher that hadn't taught me but had left the school when I was in first year. The story was that he left the Brothers and was now living and married in Raheny but everyone was mentioned except him. It was like he didn`t exist because he left and got married and became some sort of non-person.

Foucault (1978: 30) suggests that children too, were encouraged to talk about sex as part of this multiplication of sexual discourse. While the Christian Brothers highlighted the sinfulness of masturbation on retreats they also facilitated confession, a 
mechanism by which the sin would be washed away by speaking about it to a priest. Tim wanted to speak about his sexual attractions in an effort to understand them but was worried by the fear of disclosure. The diaries he wrote over a threeyear period in secondary school are only understood by an elaborate code devised by Tim to avoid disclosure about his difficult school life and his emerging gay sexuality. Here, certain keywords unlock the true meaning of his experience. The secrecy was inspired by his mother's reaction to the discovery of drawings of men that Tim had made at aged eleven and reinforced his belief that 'nothing could be written down in case it could be used as evidence against you'.

\section{Being Gay: Strategies for Coming Out and Staying In.}

'I thought it would be easier to admit to having been an IRA bomber than admit to being gay in Ireland in the seventies; at least they" $d$ say "he was doing it for Ireland'. (Tim)

The evidence from the stories in this study suggest that the men employed a variety of coping strategies to deal with the confusion caused by their new sexual feelings. The men entered the worlds of work and education ill equipped to negotiate a sexual desire that is simultaneously suppressed, misinterpreted and adapted to the specific nuances of the existing sexual norms and values within Irish society. The result is great variation in the coming out stories told by the men.

'Coming out' refers to the process by which lesbian and gay men declare openly their sexual identity, to themselves and to the broader community. It is seen as a culmination of a process beginning with nineteenth century sexology's obsessive categorisation of deviant sexualities to the gradual creation of, in Foucault's terms, a reverse discourse. This discourse allowed those categorised to speak back, to organise and to ultimately accept a definition of the self created from within rather than externally imposed by 'experts'. Plummer (1995: 89-90) identifies three main phases within this process. An early period of eighteenth and early nineteenth exploration where clandestine meeting places and networks are established, the post World War II period where huge social change facilitated the formation of conservative homosexual rights organisations, like the Mattachine Society and the post Stonewall era which fostered the 'coming out' era and the politicisation of sexuality.

Troiden (1988: 268) suggests increased inner questioning about the person's sexuality creates confusion and anxiety. The stigma surrounding homosexuality and the lack of accurate information about it increases this anxiety. William struggled to separate his public self from his private sexual feelings, a concept of denial developed by Goode (1984).

William: I was very aware that I was attracted to other guys and fantasised about having sex with other guys but joined in the same banter and jokes about girls as everyone else. I was aware of the feelings but not prepared to do anything about them. 
Monette (1994:1) refers to this mouthing of someone else's story as 'ventriloquism'. Tim too, while accepting his homosexuality at an academic level still longed for a magical solution that would end his confusion; 'I hoped I'd find a girlfriend or a girlfriend would become besotted with me'. Cass (1979) suggests avoidance as another possible strategy to be employed. Here, gay or lesbian people remove themselves from the source of the confusion, often by immersion in the opposite sex. William employed a unique variation of avoidance. After his first year in teaching training college and years of 'ventriloquism' where he attempted to pass for heterosexual he abandoned college to join the seminary.

William: God, what was I thinking (laughs), ironically at the time I saw the church as a source of social change. I was attracted by the opportunity to work in the Third World and fight for social justice and I thought it would be the best place to get things done. So there I was again in an all male environment at nineteen when my hormones were really hopping but I kept myself to myself. I didn't admit it to myself at the time but the seminary offered me an escape from questions about me and girls and offered me a way out of having sex with women which I knew I didn't want but what I didn't realise was that it would bring my attraction to men so in my face that I just couldn't ignore it any longer.

William is unclear as to his motivations for entering the priesthood. While recognising that the seminary offered him an escape for his lack of sexual interest in women he is unaware of the extent to which he confused these feelings with those for his vocation.

Kieran rejected avoidance and carried both his public heterosexual identity and his secret new homosexual identity in tandem, suggesting that the nature of Irish society at the time facilitated this dual sexual life. Women emerged from sex segregated Catholic schools believing it their responsibility to guard against immodest behaviour, remaining chaste and virginal and avoiding pregnancy at all costs (Inglis 1998b: 27). With an emphasis on courtship and dating, Kieran's relationships with women involved little sexual contact. However, it was a situation Kieran found impossible to maintain.

Kieran: I remember the first time anything happened with a man was being at a meeting in Trinity with my girlfriend, she was involved in the women's movement at the time and it was about contraception I think. Anyway, I went to the toilet without realising that this was one of Dublin's main cruising areas, and this guy gave me a blow job there and then, it was the first time and I felt so sick after it. I went outside and tried to wretch. I felt l'd done something awful with my girlfriend up in the room but after that I just couldn't stop going back.

The quote illustrates one of the most sensitive issues discussed in this study, the role of public sex in the lives of gay men in this period. It was a key point in the interviews that tested the level of identification between researcher and respondent allowing the story to be told in full, only after I had exhibited an understanding of the role that public sex had played in the sexual lives of most men in the period. Three of the men suggested in a similar fashion that public sex 'would be part of 
the sexual story of any gay man you interviewed' not just theirs. The difficulty in researching sensitive topics has been well documented (Lee 1993, Letherby 2000 , Renzetti \& Lee 1992) suffice to say that both the collaborative and the longitudinal nature of the research design facilitated the successful exploration of these areas. Edwards (1994: 99-102) identifies two public sex contexts. The informal, where a site like a public toilet is 'converted' into a site for public sex and the formal site of bathhouses or saunas. Mort (1980: 42) suggests that the British 1967 Reform Act decriminalised homosexual acts within the private sphere while continuing to criminalise the public gay male subculture that had existed for centuries. The result was a massive increase in prosecutions for gross indecency offensives until the commercialisation of desire created more formal sites for public sex like the bathhouse and sauna (Weeks 1980). In Ireland, with limited gay social venues public sexual encounters remained an important feature of gay men's lives.

Micheal: People don't really understand it, certainly not younger people. you can't see cruising guys for sex in toilets in today's light where guys are doing it just for some sexual thrill. cause we all know nowadays there's numerous means to get sex. when I was growing up there was literately no other place to meet guys. There was no way l'd be going into an IGRM club night and risk being seen by my boss or someone, I just did the casual sex thing till I was confident enough or Ireland was grown up enough for me not to care who saw me.

Kieran continued to have a further two relationships with other women subsequent to this first encounter while continuing to have causal sex with men. Much of his energy went into avoiding sexual situations, particularly with his last girlfriend, a woman from Belfast whom he describes as having little of the sexual restraint associated with her Southern counterparts.

Kieran: I can remember both of us taking our clothes off and being really frightened to do anything, I was in bed with this women and I didn't want to do anything because I thought I wouldn't have been able to, I thought I won't be able to get a hard-on and I just wanted to run away and avoid all occasions where I thought l'd end up in her flat. As far as she was concerned nothing was amiss. I don't think my reluctance raised any questions in her head. she certainly wouldn't have jumped to the conclusion that I was gay, not then. But it was an unhappy time that's for sure.

That these sexual encounters with other men have gone undocumented is not surprising. For Weeks (1985) the backlash against gay public sex in particular was rooted in society's rejection of sex for pleasure alone, when sex became devoid of the conventional ties and responsibilities. In seeking to understand the absence of the coming out story in Ireland we must also appreciate the marginalisation of all sexual activity outside the context of marriage. Such sexual activity beyond this context was seen to be morally corrupt and an affront to the natural order of God. Gay men that were known to have sexually transgressed repented not in Magdalen homes like thousands of similarly fallen women but were exposed in court, their names published in newspapers (Hug 1999: 207). Stigmatised by their arrest and 
court appearance most pleaded guilty to the charges against them allowing the legislation to remain uncontested and the real stories of gay men in the 1970 s to remain unheard.

\section{Conclusion}

Personal narratives tell us much more than just individual life stories. They are socially constructed, recalling significant past life events often in an attempt to create a current sense of self and identity. The stories that are produced often play a variety of social roles in maintaining or transforming individual lives and contributing to a shared history that has the capacity to achieve far reaching societal change. In presenting the stories of some Irish gay men, the key sociological endeavour has been to reveal the vectors that have shaped a uniquely Irish coming out experience and explain the processes that have either enabled or suppressed that story from being told. These stories support the view that the coming out experience is an uneven one. Attempts to place it within an Irish modernisation perspective are inadequate. The Dublin communities in which the men lived revealed greater cohesion, community and surveillance than suggested in earlier commentaries (see Berman 1988). The stories reveal how it has been the traditional, denominational forces in Irish society that have shaped the coming out experience. The sexual misinformation and confusion encouraged by the Christian Brothers in their schools and the role of Gaelic sport on their playing fields successfully stigmatised some men as gay, a definition that they would have to negotiate and contest over the next twenty years.

I do not suggest however that the men passively accepted the negative definitions of homosexuality they received. There is evidence in the stories where the men resisted these definitions and where the existing practices by which the men organised their sexual lives prior to their coming out continued often in tandem with the new social gay identity they had adopted. Like Connell's life stories (1995: 93-181) there is a high degree of agency in the decisions the men have taken about their gay sexuality and have led them to explore the distinctly Irish solutions of celibacy and seminary. Plummer (1995: 87) suggests that for narratives to flourish there has to be a community ready to consume them and clearly this was not the case in 1970s Ireland. There is evidence to suggest that the day of the gay and lesbian modernist narrative has now passed. In Ireland, as elsewhere they are to replaced with stories that reflect a multiplicity of experience where sexuality intersects with class and ethnicity (Savin-Williams 1998; Humphrey 1990; Burke 1993; Kennedy and Davis 1993). 


\section{Notes}

1 A brief note on terminology is necessary. All four men referred to in this study identified themselves as gay. In referring to the gay movement, this refers to the gay and lesbian movement unless otherwise stated.

2 Plummer (1995: 50) sees these stories as containing 'significant transformations' where there is a move from secrecy. suffering and then often through a life changing event a move towards survival and ultimate emancipation.

3 Unlike most of Western Europe, homosexuality remained criminalised in Ireland under the 1861 Offences Against the Person Act. It was extended in 1885 by the Labouchere Amendment which imposed a punishment of two years hard labour for acts of gross indecency between men. See Lemke (1991) for stories of gay men living under similar oppressive conditions in East Germany.

4 There is dispute as to when the 'modern homosexual' was constituted and under what circumstances with Weeks (1980) and D'Emilio (1992) locating it within the rise of modern capitalism and the emergence of the bourgeois family and Norton (1997: 61-97) placing the construction in a broader historical perspective.

5 Bravmann (1996) adapts this idea from Allan Berube's paper 'Fitting in: Expanding Queer Studies beyond Gay Identity and Coming out' at the Annual Lesbian, Bisexual and Gay Studies Conference. Harvard University. Oct. 26-8. 1990.

6 Within Men's Studies, the use of personal narratives to explore men's experiences appears to be under utilised. See Jackson (1990: 252-279) for a discussion of how life histories can uncover the social relations and cultural practices that have 'masculinized' men.

7 I use the term hegemonic masculinity as defined by Connell (1995: 77).

8 William was born in Dublin in 1956. He attended a local Christian Brothers School and later St. Patrick's College, Drumcondra. He lived with his parents, three brothers and two sisters until he was nineteen when he left home to join the seminary. After three years he began sexual relationships with men in his order and faced with a crisis that threatened his belief in his vocation to the priesthood, he left the seminary. When these interviews took place William was teaching in a Dublin school and living with his partner of six years.

\section{References}

Atkinson, R. 1988 The Life Story Interview: Thousand Oaks, [CA]: Sage.

Berman, M. 1988 All That is Solid Melts into Air: The Experience of Modemity. New York: Penguin.

Boyd. C. 1986 Out for Ourselves: The Lives of Irish Lesbians and Gay Men. Dublin: Dublin Lesbian and Gay Men's Collective.

Bravmann, S. 1996 'Postmodernism and queer identities' pp. 333-361 in S. Seidman, Queer' Theory/Sociology. Cambridge: Blackwell.

Breen, R, D.F Hannan. D.B Rottman and C.T Whelan 1990 Understanding Contemporary Ireland. Dublin: Gill and MacMillan.

Burke. M. 1993 Coming Out of the Blue. London: Cassells.

Cass, V.C. 1979 'Homosexual identity formation: A theoretical model', Journal of Homosexuality, 4:3:255-66.

Connoll, R.W. 1995 Masculinities. Cambridge: Polity Press. 
Connolly, L. 2002 The Irish Women's Movement: From Revolution to Devolution. Basingstoke: Palgrave.

D'Emilio, J. 1992 Making Trouble: Essays on Gay History, Politics and the University. New York: Routledge.

Edwards, T. 1994 Erotics \& Politics: Gay Male Sexuality, Masculinity and Feminism. London and New York: Routledge.

Fahey, T. 1995 'Family and household in Ireland,' pp. 205-234 in P. Clancy, S. Drudy, K. Lynch, and L. O'Dowd (eds), Irish Society: Sociological Perspectives. Dublin: Institute of Public Administration.

Fahey, T. 1999 'Religion and sexual culture in Ireland' pp. 53-70 in F.X. Eder, L.A. Hally and G. Hekma (eds), Sexual Cultures in Europe: National Histories. Manchester: Manchester University Press.

Foucault, M. 1978 The History of Sexuality, Volume I: An Introduction. London: Penguin.

Gathorne-Hardy, J. 1977 The Public School Phenomenon 597-1977. London: Hodder and Stoughton.

Goldthorpe, J.H. and C.E Whelan (eds) 1992 The Development of Industrial Society in Ireland. Oxford: Oxford University Press.

Gilbert, R. and P. Gilbert 1998 Masculinity Goes to School. London and New York: Routledge.

Goode, E. 1984 Deviant Behaviour. Englewood Cliffs: Prentice-Hall.

Hall Carpenter Archives 1989 Walking After Midnight: Gay Men's Life Stories. London: Routledge.

Hug, C. 1999 The Politics of Sexual Morality in Ireland. Basingstoke: Macmillan.

Humphrey, M.A. 1990 My Country, My Right to Serve: Experiences of Gay Men and Women in the Military, World War II to the Present. New York: HarperCollins.

Inglis, T. 1998a Moral Monopoly: The Rise and Fall of the Catholic Church in Modern Ireland. Dublin: University College Dublin Press.

Inglis. T. 1998b Lessons in Irish Sexuality. Dublin: University College Dublin Press.

Jackson, D. 1990 Unmasking masculinity:A Critical Autobiography. London: Unwin Hyman. Kearney, R. 2002 On Stories. London: Routledge.

Kennedy, E. and M. Davis 1993 Boots of Leather, Slippers of Gold: The History of a Lesbian Community. New York: Routledge.

Keogh, D. 1996 Edmund Rice 1762-1844. Dublin: Four Courts Press.

Lee, R. 1993 Doing Research on Sensitive Topics. London: Sage.

Lentin, R. 2000 Israel and the Daughters of the Shoah. Oxford: Berghahn Books.

Letherby, G. 2000 'Dangerous liaisons: auto/biography in research and research writing.' pp. 91-113 in G. Lee-Treweek, and S. Linkogle (eds), Danger in the Field: Risk and Ethics in Social Research. London: Routledge.

Lemke, J. 1991 Gay Voices from East Germany. Indiana University Press: Bloomington.

Lynch, K. 2000 'The role of emancipatory research in the academy' pp. 73-104 in A. Byrne. and R. Lentin (eds), (Re)searching Women, Feminist Research Methodologies in the Social Sciences in Ireland. Dublin: Institute of Public Administration.

Mac an Ghaill, M. 1994 The Making of Men, Masculinity, Sexualities and Schooling. Buckingham: Open University Press.

Mangan, J.A. \& Walvin, J. (eds) 1987 Manliness and Morality: Middle-class masculinity in Britain and America 1800-1940. Manchester: Manchester University Press.

Martin, B. 1988 'Lesbian Identity and Autobiographical Difference\{s\}.' pp.77-103 in B. Brodzki, and C. Schenck (eds), Life Lines: Theorizing Women s Autobiography. Ithaca: Cornell University Press. 
Messner, M. 1987 'The Life of a man's seasons: Male identity in the lifecourse of an athlete,' pp. 53-67 in M. Kimmel (ed). Changing Men: New Directions in Research on Men and Masculinity. Newbury Park: Sage.

Milotte, M. 1997 Banished Babies: The Secret History of Ireland's Baby Export Business. Dublin: New Island Books.

Monette, P. 1994 Becoming a Man: Half a Life Story. Abacus: London.

Mort, F. 1980 'Sexuality: regulation and contestation,' pp. 38-51 in Gay Left Collective (eds) Homosexuality: Power and Politics. London: Allison \& Busby.

Nardi, P.M, D. Sanders and J. Marmor 1994 Growing Up Before Stonewall, Life Stories of Some Gay Men. New York: Routledge.

Nic Ghiolla Phadraig. M. 1995 'The power of the catholic Church in the Republic of Ireland,' in pp. 593-619 P. Clancy, S. Drudy, K. Lynch, L. O'Dowd (eds), Irish Society: Sociological Perspectives. Dublin: Institute of Public Administration.

Norton. R. 1997 The Myth of the Modem Homosexual: Queer History and the Search for Cultural Unity. London: Cassell.

O'Suilleabhain, S. 1973 Storytelling in Irish Tradition. Cork: Mercier.

Plummer, K. 1975 Sexual Stigma: An Interactionist Account. London: Routledge and Kegan Paul.

Plummer, K. (ed) 1992 Modern Homosexualities. London: Routledge.

Plummer, K. 1995 Telling Sexual Stories. London: Routledge.

Porter, K. and J. Weeks 1991 Between the Acts: Lives of Homosexual 1885-1967. London: Routledge.

Pronger, B. 1990 'Gay jocks: a phenomenology of gay men in athletics,' pp. 141-152 in D. Sabo and M. Messner (eds) Sport, Men and the Gender Order: Critical Feminist Perspectives. Champaign, IL: Human Kinetics.

Preston, J. (ed) 1991 Hometowns: Gay Men Write About Where They Belong. New York: Dutton.

Raftery, M. 1999 Suffer Little Children: The Inside Story Of Ireland's Industrial School. Dublin: New Island.

Reinharz, S. 1992 Feminist Methods in Social Research. Oxford: Oxford University Press.

Renzetti, C.M and R.M Lee (eds), 1992 Researching Sensitive Topics. Newbury Park, CA: Sage.

Rose, K. 1994 Diverse Communities: The Evolution of Lesbian and Gay Politics. Cork: Cork University Press.

Rose, K. 1995 'The tenderness of the peoples,' pp.71-85 in 1. O'Carroll and E. Collins (eds), Lesbian and Gay Visions of Ireland. London: Cassell.

Sabo, D. and R. Runfola (eds) 1980 Jocks: Sports and Male Identity. Englewood Cliffs: Prentice-Hall.

Savin-Williams. R.C. 1998 And Then I Became Gay. New York: Routledge.

Stanley, L. and S. Wise 1993 Breaking Out Again: Feminist Ontology and Epistemology. London: Routledge.

Sudgen, J. and A. Bairner 1993 Sport, Sectarianism and Society in a Divided Ireland. Leicester: Leicester University Press.

Troiden. R. 1988 'A model of homosexual identity formation,' pp. 261-278 in P.M Nardi, and B.E Schneider (eds), Social Perspectives in Lesbian and Gay Studies. London \& New York: Routledge.

Weeks, J. 1977 Coming Out: Honosexuality Politics in Britain, from Nineteenth Century to the Present. London: Quartet. 
Weeks, J. 1980 'Capitalism and the organisation of sex' pp. 11-20 in Gay Left Collective (eds). Homosexuality: Power and Politics. London: Allison \& Busby.

Weeks, J. 1985 Sexuality and its Discontents. London: Routledge.

Whitson, D. 1990 'Sport in the social construction of masculinity,', pp. 19-30 in M.A. Messner and D.F Sabo (eds), Sport, Men and the Gender Order. Champaign: Human Kinetics Books.

Wolpe, A-M. 1988 Within School Walls: The Role of Discipline, Sexuality and the Curriculum. London: Routledge. 